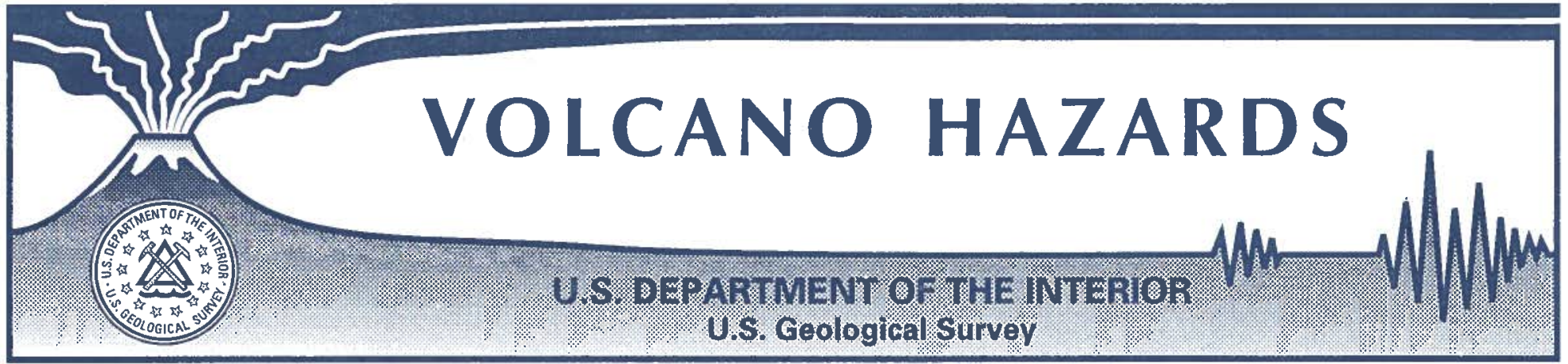

\title{
HISTORY AND HAZARDS OF MOUNT RAINIER, WASHINGTON
}

Mount Rainier is an active volcano that first erupted about half a million years ago. Because of Rainier's great height $(14,410$ feet above sea level) and northerly location, glaciers have cut deeply into its lavas, making it appear deceptively older than it actually is. Mount Rainier is known to have erupted as recently as in the 1840 s, and large eruptions took place as recently as about 1,000 and 2,300 years ago.

Mount Rainier and other similar volcanoes in the Cascade Range, such as Mount Adams and Mount Baker, erupt much less frequently than the more familiar Hawaiian volcanoes, but their eruptions are vastly more destructive. Hot lava and rock debris from Rainier's eruptions have melted snow and glacier ice and triggered debris flows (mudflows) - with a consistency of churning wet concrete - that have swept down all of the river valleys that head on the volcano. Debris flows have also formed by collapse of unstable parts of the volcano without accompanying eruptions. Some debris flows have traveled as far as the present margin of Puget Sound, and much of the lowland to the east of Tacoma and the south of Seattle is formed of prehistoric debris from Mount Rainier (Figure 1).

The northeast part of Mount Rainier slid away about 5,600 years ago as part of a catastrophic collapse similar to, but much larger than, that of May 18, 1980 at Mount St. Helens. Debris from this collapse created the
Osceola and Paradise mudflows that traveled down the White and Nisqually Rivers, reaching Puget Sound and pushing out the shoreline by as much as 10 miles. The scar from this collapse was a horseshoeshaped crater, about 1.25 miles wide, open to the northeast. Since the collapse, lava flows and avalanches of hot lava fragments have erupted from the crater and largely filled it, forming the present summit cone of Mount Rainier.

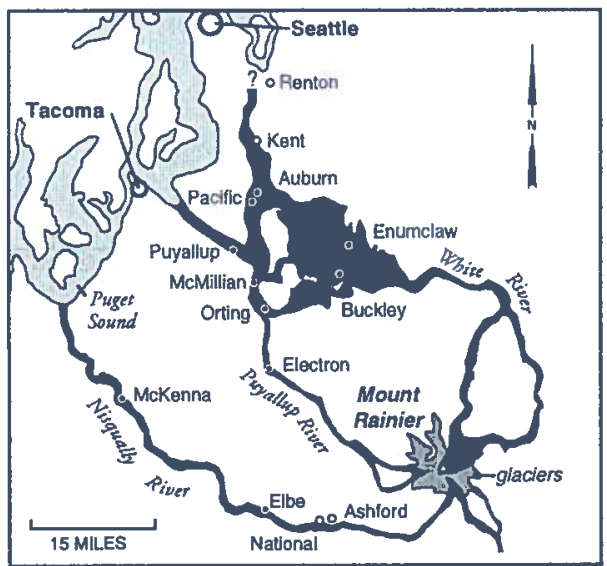

Figure 1. Map showing areas innundated by mudflows (black) from Mount Rainier in the last 5,600 years.

Very little of the young lava can actually be seen, because it is almost completely concealed by snow and ice. The summit lava cone is most clearly recognized from the northeast (Sunrise), where it floors the large Emmons and Winthrop Glaciers that slope smoothly up to Rainier's summit (Figure 2). Broad lobes on the glaciers' surfaces show the locations of the youngest lavas from Rainier's summit, now buried under hundreds of feet of ice. The summit itself is formed of two small overlapping craters, each about a quarter mile in diameter; the younger of these forms a nearly perfect circle of radiallyoutward-sloping lavas. The shallow floors of these craters are filled with snow and ice, but the raised rims are snow-free year-round because of high winds and because much of the ground is still hot. Steam or warm mist, at or just below boiling temperature, rises from the crater rims in many areas and has melted an intricate system of caves into the base of the crater-filling ice. On calm days, a faint odor of sulfur can also be smelled. The hot ground, steam, and sulfur smell, as well as the littleeroded shape of the summit craters attest to Rainier's recent activity.

Volcanic rocks older than the summit cone form all but the highest slopes visible from other directions and can be recognized by their craggy appearance, caused by deep glacial erosion. The stair-step or banded look of these older rocks is caused by ice and landslides having cut into the lavas and exposed their dense interiors, that form cliffs, and their rubbly tops that form the intervening ledges, often covered with snow. Many of the lavas that make up upper Mount Rainier overlie, and are thus younger than, a lava that erupted 40,000 years ago (as measured by radiometric techniques), but are older than the 5,600-year-old collapse event. Many of these lavas were erupted during the last great ice age. 


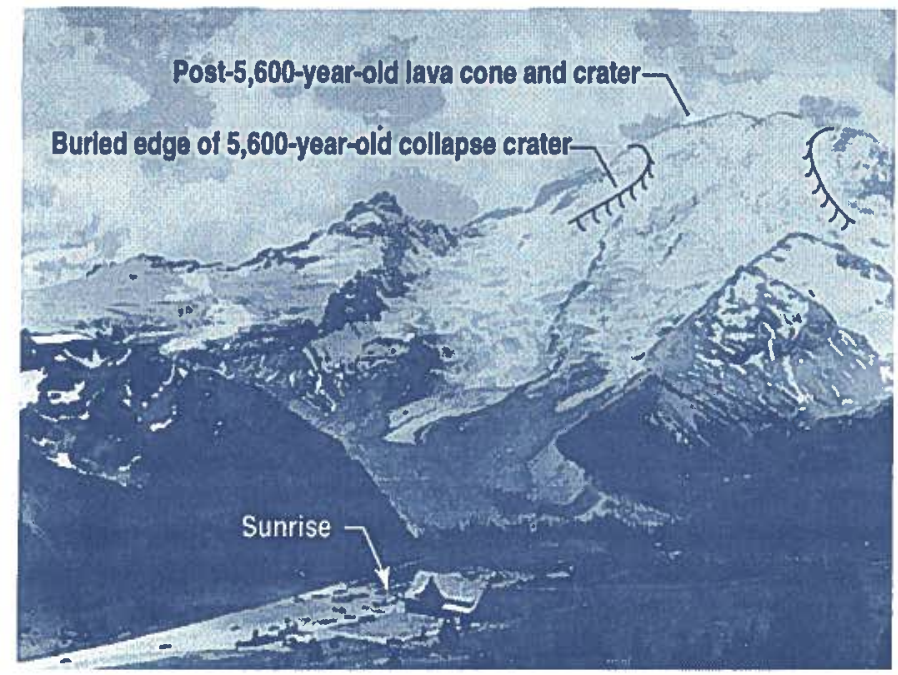

Figure 2. View of Mount Rainier from the northeast showing post-5,600-year-old lava cone and crater, buried edge of collapse crater (hachured line), and older volcanic rocks (left and right of the summit and in the lower foreground).

Lavas on Rainier's lower slopes formed flows to several hundred feet thick that now hold up most of the ridges radiating from Mount Rainier. Many of the measured eruption ages cluster in the interval 130,000 to 90,000 years ago, perhaps indicating a period of particularly voluminous volcanic activity.

There is nothing to suggest that volcanic activity has ended at Mount Rainier. Mount Rainier will surely erupt again, and this will affect people who live in the surrounding areas or who visit Mount Rainier National Park. Experience at other volcanoes indicates that renewed eruptions will likely be preceded by weeks or months of small earthquakes centered beneath the volcano. These earthquakes can be accompanied by swelling or other changes in the shape of the volcano, as well as changes in ground temperatures and the amount and type of gas released from the volcano. Earthquakes at Mount Rainier and other Cascade volcanoes are monitored by the University of Washington and the U.S. Geological Survey (USGS), and the volcanoes' shapes are measured regularly by staff of the USGS's Cascades Volcano Observatory, located in Vancouver, Washington.

An eruption would probably begin with small steam blasts located at the summit, but could escalate in size and intensity, perhaps leading to a release of new magma (hot, molten rock). Depending on the amount of magma released, the eruptions could have relatively minor effect on the surrounding area or could produce large, destructive floods and debris flows, affecting areas far from the volcano. The shaking by earthquakes or explosions will also dislodge masses of unstable rock; the resulting rockslides could damage Park facilities. Particularly large landslides could also create destructive, fartraveling debris flows.

There is no immediate indication of renewed activity at Mount Rainier. However, the rapidly increasing population in the southern Puget Sound region, and the expansion of communities near Mount Rainier, has led to an increased overall risk to people and property once activity resumes. Scientists from universities and the govenment have responded by increasing the level of monitoring at Mount Rainier. New studies have been started aimed at learning the style and size of Rainier's past eruptions to predict better the nature of future activity, mapping the locations of particularly weak hydrothermallyaltered rocks that would be more prone to collapse, and determining the structure of the rocks below the volcano so that any new earthquake swarms can be interpreted quickly and accurately.

The potential hazards posed by Mount Rainier led to its inclusion as one of sixteen volcanoes worldwide to be designated Decade Volcanoes. The Decade Volcano initiative is part of a United Nations program aimed at better utilizing science and emergency management to reduce the severity of natural disasters. The Decade Volcanoes are the focus of coordinated earth-science studies and land-use planning to learn the best ways to reduce the risks to life and property from volcano-related hazards. Products from Decade Volcano studies at Mount Rainier will include updated maps showing the areas and levels of hazards, maps showing the locations and ages of Rainier's lavas and debris flow deposits, and reports on the style and size of selected eruptions and on the structure and makeup of the rocks forming Mount Rainier and its underpinnings.

- Thomas W. Sisson

For additional information about volcano hazards at Mt. Rainier or other volcanoes, contact:

\section{U.S. Geological Survey}

Cascades Volcano Observatory

5400 MacArthur Blvd.

Vancouver, Washington 98661

Telephone: (360) 696-7693

Fax: (360) 696-7866

E-mail: cvo@pwavan.wr.usgs.gov Internet:http://vulcan.wr.usgs.gov/ 